\title{
Pemanfaatan Model Weather Research and Forecasting (WRF) dalam Analisis Cuaca terkait Hujan Lebat Batam 30-31 Januari 2011
}

\author{
Akhmad Fadholi, ${ }^{*}$ Fitria Puspita Sari, Purwo Aji, dan Ristiana Dewi \\ Program Studi Diplom IV Meteorologi, Sekolah Tinggi Meteorologi, Klimatologi, \\ dan Geofisika, Jl. Perhubungan I no. 5, Pondok Betung, Bintaro, Tangerang 15221
}

\begin{abstract}
Intisari
Hujan lebat di Batam tanggal 30-31 Januari 2011 menyebabkan banjir. Nilai hujan akumulasi hasil obsevasi pada 31 Januari 2011 sebesar $414.5 \mathrm{~mm}$, jauh melebihi ambang batas ekstrim untuk curah hujan yang hanya 50 $\mathrm{mm} /$ hari. Adanya hujan lebat tidak lepas dari dinamika parameter-parameter cuaca yang beraitan erat dengan proses konveksi dan pembentukan awan. Pada penulisan ini, analisa kondisi cuaca menggunkan Weather Research and Forecasting (WRF) satu domain dengan resolusi 6 kilometer $(\mathrm{km})$ pada $1^{\circ} \mathrm{LU}$ dan $104^{\circ} \mathrm{BT}$. Beberapa parameter cuaca seperti suhu udara, kelembaban tiap lapisan $(\mathrm{RH})$, aliran massa udara (angin), dan curah hujan menunjukkan hasil yang sangat signifikan dimana nilai dari parameter-parameter tersebut mendukung adanya proses konveksi untuk membentuk awan konvektif (Cumulonimbus) secara terus menerus dengan masa hidup yang lama. WRF dengan setting-an default dan domain tanpa nesting ternyata sduah cukup mampu menggambarkan kondisi cuaca secara umum. Adanya perbedaan laju curah hujan hasil output model dengan observasi antara 6-12 jam pada awal data merupkan proses spin-up (pemanasan untuk mendapatkan data yang stabil pada hasil model). Data citra satelit MTSAT (Multi-functional Transport Satellite) digunakan sebagai pembanding hasil model, dimana pada gambar terdapat warna putih Coldest Dark Grey (CDG) yang mengindikasikan adanya awan dengan suhu puncak lebih rendah dari $-80^{\circ} \mathrm{C}(\mathrm{Cb})$. Gambar ini semakin memperjelas bahwa pada kasus hujan lebat yang mengguyur Batam pada 30-31 Januari dengan cukup baik direpresentasikan oleh model WRF.
\end{abstract}

\begin{abstract}
Heavy rain in Batam 30-31 January 2011 causes flood. The accumulation of rainfall until 31 January 2011 is $414.5 \mathrm{~mm}$, it exceeds BMKG's threshold about intensity of extreme condition, that more than $50 \mathrm{~mm} / \mathrm{day}$. It is related to dynamic of weather's parameter, especially with convection process and clouds. In this case, weather condition analysis uses Weather Research and Forecasting (WRF) Model one domain with 6 kilometer (km) resolution on $1^{\circ} \mathrm{N}$ and $104^{\circ} \mathrm{E}$. Some weather's parameters show significant result. Their fluctuations prove there is a strong convection that produces convective cloud (Cumulonimbus) so that cloud has a long lifetime and produce rain. Default setting and without nesting on WRF Model show good output to represent weather's condition commonly. Difference between output rainfall rate of observation result and output of model around 612 hours is because spinning-up of processing. Satellite Images of MTSAT (Multifunctional Transport Satellite) are used as a verification data to prove the result of WRF. White color of satellite image is Coldest Dark Grey (CDG) that indicate there is cloud's top which temperature lower than $-80^{\circ} \mathrm{C}$. This image consolidate that the output of WRF is good enough to analyze Batam's condition when the case happened.
\end{abstract}

KATA KUNCI: heavy rain, flood, WRF, satellite image

\section{PENDAHULUAN}

Pada tanggal 31 Januari 2011, hujan lebat selama dua hari mengakibatkan banjir di kota Batam [1]. Hujan lebat yang menyebabkan banjir tersebut melanda beberapa titik di kota Batam, Tanjungpinang, dan Karimun. Di kota Batam, se-

\footnotetext{
*E-MAIL: yudhistira407@gmail.com
}

lain menyebabkan banjir, hujan lebat juga menyebabkan tanah longsor di perumahan wilayah Bengkong. Banyaknya kerugian yang diakibatkan, mengindikasikan adanya kondisi hujan yang sangat lebat yang terjadi secara akumulasi selama lebih dari satu hari [2].

Salah satu fenomena cuaca ekstrim menurut Badan Meteorologi Klimatologi dan Geofisika [3] adalah hujan lebat dengan intensitas lebih dari $20 \mathrm{~mm} / \mathrm{jam}$ atau lebih dari 50 $\mathrm{mm} /$ hari. Dilihat dari data curah hujan, kasus banjir yang terjadi di kota Batam merupakan salah satu contoh banjir yang diakibatkan oleh hujan lebat dengan intensitas jauh melebihi 


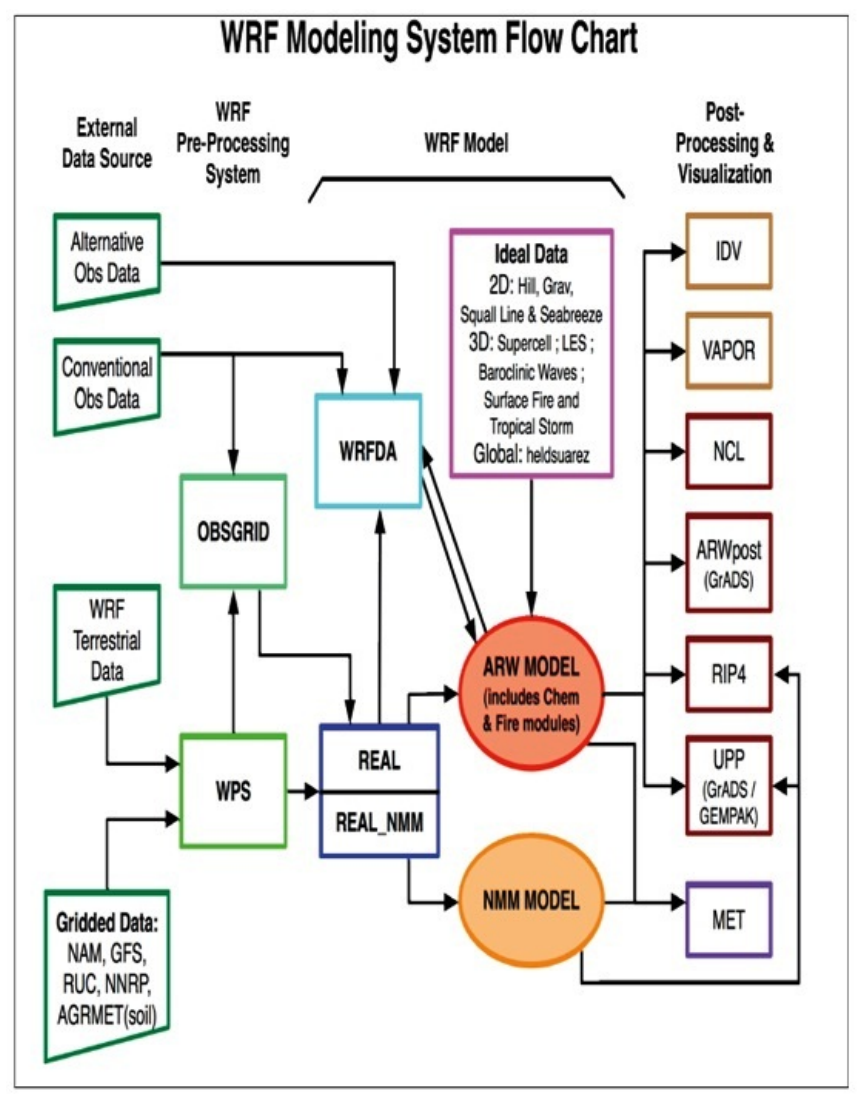

Gambar 1: Diagram alir proses running WRF [4].

ambang batas nilai ekstrim yang ditetapkan oleh BMKG.

Kondisi cuaca ekstrim merupakan output dari kondisi signifikan yang terjadi terhadap parameter-parameter cuaca. Termasuk hujan lebat, ada beberapa parameter cuaca yang yang menyebabkan hal ini terjadi. Parameter-parameter tersebut antara lain seperti kondisi angin, kelembaban, dan suhu, dimana jika parameter-parameter cuaca tersebut berada dalam kondisi yang mendukung terjadinya proses konveksi yang kuat maka akan membentuk awan konvektif yang dapat memproduksi hujan dengan curahan yang besar.

Dalam penelitian ini, untuk melakukan analisis digunakan simulasi model dengan menggunakan model cuaca numeric WRF. Hal ini dilakukan sebagai salah satu langkah untuk mengetahui kondisi parameter-patrameter cuaca yang mendukung (menyebabkan) terjadinya hujan yang sangat lebat. Selain itu juga sebagai pembanding ditampilkan data citra satelit MTSAT dan data curah hujan (model) dengan curah hujan dari hasil pengamatan di lapangan yaitu di Stasiun Meteorologi Hang Nadim Batam.

WRF merupakan salah satu model regional yang saat ini banyak dikembangkan oleh kalangan meteorologist. WRF dapat memodelkan kondisi atmosfer di suatu wilayah sehingga dapat membantu dalam mempelajari suatu kejadian meteorologi dengan lebih baik [4]. Diagram alir proses running WRF ditunjukkan Gambar 1.

Weather Research and Forecasting - Advanced Research WRF (WRF-ARW) merupakan model generasi lanjutan sis- tem simulasi cuaca numerik skala meso yang didesain untuk melayani simulasi operasional dan kebutuhan penelitian atmosfer. Model ini mempunyai keistimewaan inti dinamik yang berlipat, variasi 3-dimensional (3DVAR) sistem asimilasi data dan arsitektur perangkat lunak yang mengijinkan untuk melakukan komputasi secara paralel dan sistem ekstensibel. WRF cocok untuk aplikasi yang luas dari skala meter sampai ribuan meter.

Usaha untuk mengembangkan WRF merupakan kerjasama kolaborasi, yang pada prinsipnya antara National Center for Atmospheric Reasearch (NCAR), National Oceanic and Atmospheric Administration (NOAA), National centers for Environmental Prediction (NCEP) dan Forecast systems Laboratory (FSL), dan Air Force Weather Agency (AFWA), Naval Reasearch Laboratory, Universitas Oklahoma dan Federal Aviation Administration (FAA).

WRF merupakan model yang fleksibel, seni, dan memiliki code portable yang efisien untuk lingkungan computing dan pararel superkomputer sampai laptop. WRF modular, singlesource code dapat dikonfigurasi untuk penelitian dan aplikasi operfasional. Memiliki pilihan spektrum fisi dan dinamis yang diperoleh dari percobaan dan hasil komunitas ilmuan. Terdapat WRF-Var yang merupakan sistem variasi data asimilasi yang dapat memadukan data observasi untuk mengoptimalkan kondisi inisial model, dan juga WRF-Chem model untuk memodelkan kimiawi udara (air chemistry) [5].

\section{METODE PENELITIAN}

Sebagai syarat awal dan syarat batas model digunakan data FNL (Final Analysis) dari National Centers for Environmental Prediction - National Center for Atmospheric Research (NCEP-NCAR) dengan interval waktu selama 6 jam, yang memiliki resolusi $1^{\circ} \times 1^{\circ}$ yang dapat didownload melalui situs http://rda.ucar.edu. Sementara data pengamatan permukaan diperoleh dari hasil pengamatan stasiun meteorology Hang Nadim Batam yang berkoordinat $1,1^{\circ}$ Lintang Utara dan 104,1 $1^{\circ}$ Bujur Timur.

Oleh karena keterbatasan model WRF yang ada pada saat dilakukan percobaan, maka dalam percobaan ini domain tanpa nesting. Yakni langsung mengambil domain dengan resolusi $6 \mathrm{~km}$, dengan data yang diolah selama 30 jam, terhitung dari 30 Januari 2011 pukul 00:00 UTC sampai dengan 31 Januari 06:00 UTC. Adapun untuk lebih jelasnya mengenai proses running yang dilakukan, dapat dilihat pada Tabel I.

Setelah proses running model WRF selesai, maka dihasilkan banyak parameter yang dapat digunakan sebagai bahan analisis. Namun pada penelitian ini, beberapa parameter yang diambil sebagai bahan analisis antara lain temperature, kelembaban, angin dan curah hujan.

Sebagai pembanding, data citra satelit MTSAT dengan suhu puncak awan yang terangkum dalam grafik jaman (perhari) untuk membandingkan dengan kondisi perawanan yang sedang terjadi. Selain itu hasil simulasi curah hujan akumulatif dibandingkan dengan hasil pengamatan (tiap tiga jam). 
TABEL I: Informasi Proses Running WRF.

\begin{tabular}{ll}
\hline \hline TIPE GRID & Arakawa C-Grid \\
KATEGORI LAND USE & USGS (Mixed Dyland/Irregated Coplaid and Pasture) \\
DIMENSI GRID BARAT-TIMUR & 149 \\
DIMENSI GRID SELATAN-UTARA & 110 \\
DIMENSI GRID DASAR-PUNCAK & 28 \\
RESOLUSI GRID PADA SB. X (DX) & $6000 \mathrm{~m}$ \\
RESOLUSI GRID PADA SB. Y (DY) & $6000 \mathrm{~m}$ \\
PUSAT LINTANG & $1^{\circ} \mathrm{LU}$ \\
PUSAT BUJUR & $104^{\circ}$ BT \\
SKEMA MIKROFISIK & WRF Single Moment 5 Class Scheme \\
SKEMA RADIASI GEL. PANJANG & RRTM (Rapid Radiation Transfer Model) Scheme \\
SKEMA RADAIASI GEL. PENDEK & Dudhia \\
OPSI LAP. PERMUKAAN & MM5 \\
OPSI PERMUKAAN DARAT & NOAH Land Surface \\
OPSI LAP. BATAS (PBL) & YSU (Yonsei University) Scheme \\
OPSI CUMULUS & KF (Kain-Fritsch) Scheme \\
SUMBER INPUT PERMUKAAN & WPS/geogrid \\
UPDATE DATA SST & No SST Update \\
FEEDBACK & One-way nesting \\
LANGKAH WAKTU INTEGRASI & 30 detik \\
\hline \hline
\end{tabular}

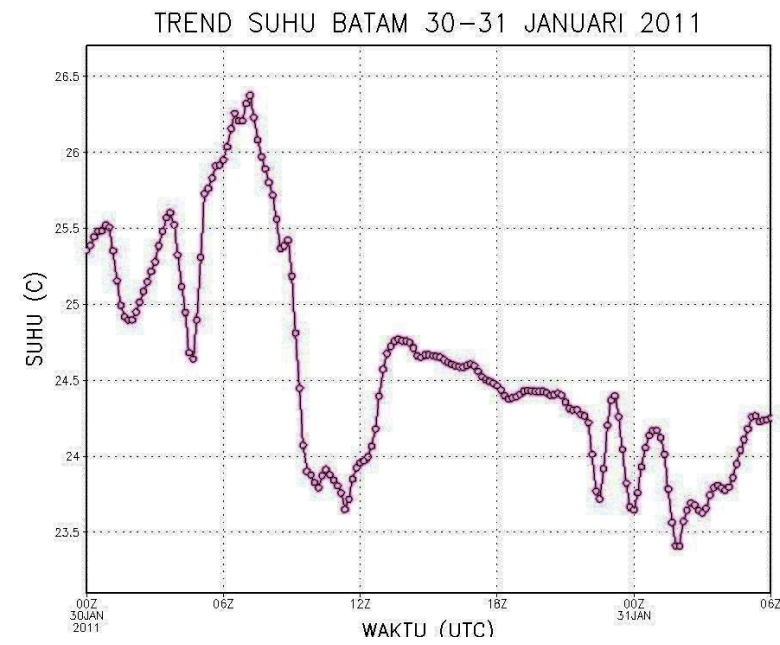

Gambar 2: Trend suhu udara.

\section{ANALISIS DAN PEMBAHASAN}

\section{Analisis Suhu}

Gambar 2 merupakan grafik suhu selama rentang waktu 30 jam di Batam. Pada rentang waktu tersebut Batam tengah diguyur hujan dari intensitas tinggi sampai rendah. Diketahui bahwa suhu mengalami fluktuasi meskipun masih dalam rentang sekitar $(1-1,5)^{\circ} \mathrm{C}$, dimana ketika sebelum hujan intensitas tinggi mengguyur Batam (30/16.00UTC - 31/03.00 UTC), suhu sempat naik, artinya sempat terjadi pemanasan yang menambah nilai buoyancy udara ke atas untuk pembentukan awan. Sehingga setelah adanya kenaikan suhu, diindikasikan udara naik dan kemudian menambah partikel udara pada awan yang masih terbentuk sebelumnya. Sehingga

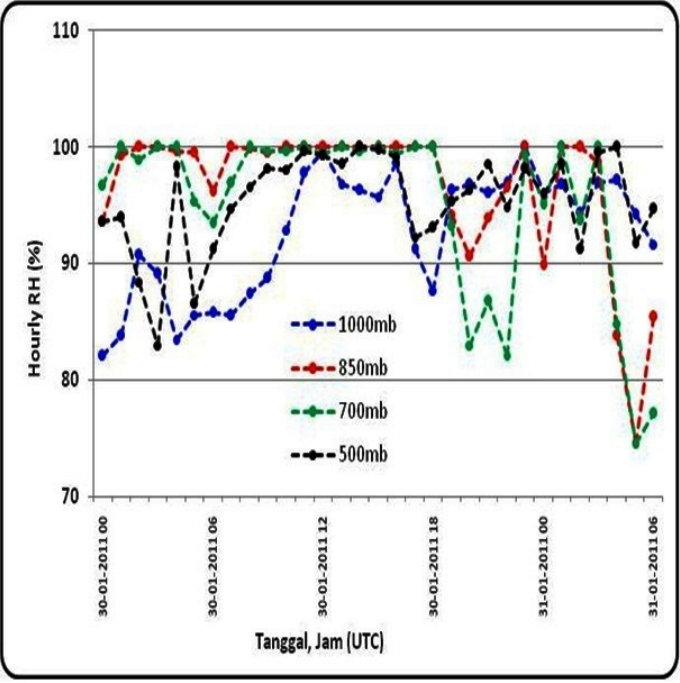

Gambar 3: Kelembaban udara tiap lapisan.

awan yang terbentuk semakin besar dan kandungan udaranya semakin tebal, sehingga ketika awan telah tidak cukup mampu menampung partikel udara, dia meluruh dalam bentuk hujan.

\section{Analisis Angin}

Analisis kelembaban (RH) pada beberapa lapisan ketinggian (Gambar 3) menunjukkan adanya kondisi yang sangat signifikan. Kelembaban udara yang dianalisis melalui model WRF dari lapisan 1000 hinga 500 milibar berkisar antara 80 hingga $100 \%$. Pola yang terlihat pada gambar sangat dapat dipahami sebagai suatu kondisi yang menunjang proses konveksi (pembentukan awan) yang sangat kuat. Nilai kelembaban yang mencapai hamper $100 \%$ pada lapisan 1000 hingga 500 milibar menunjukkan lapisan ketebalan kelem- 

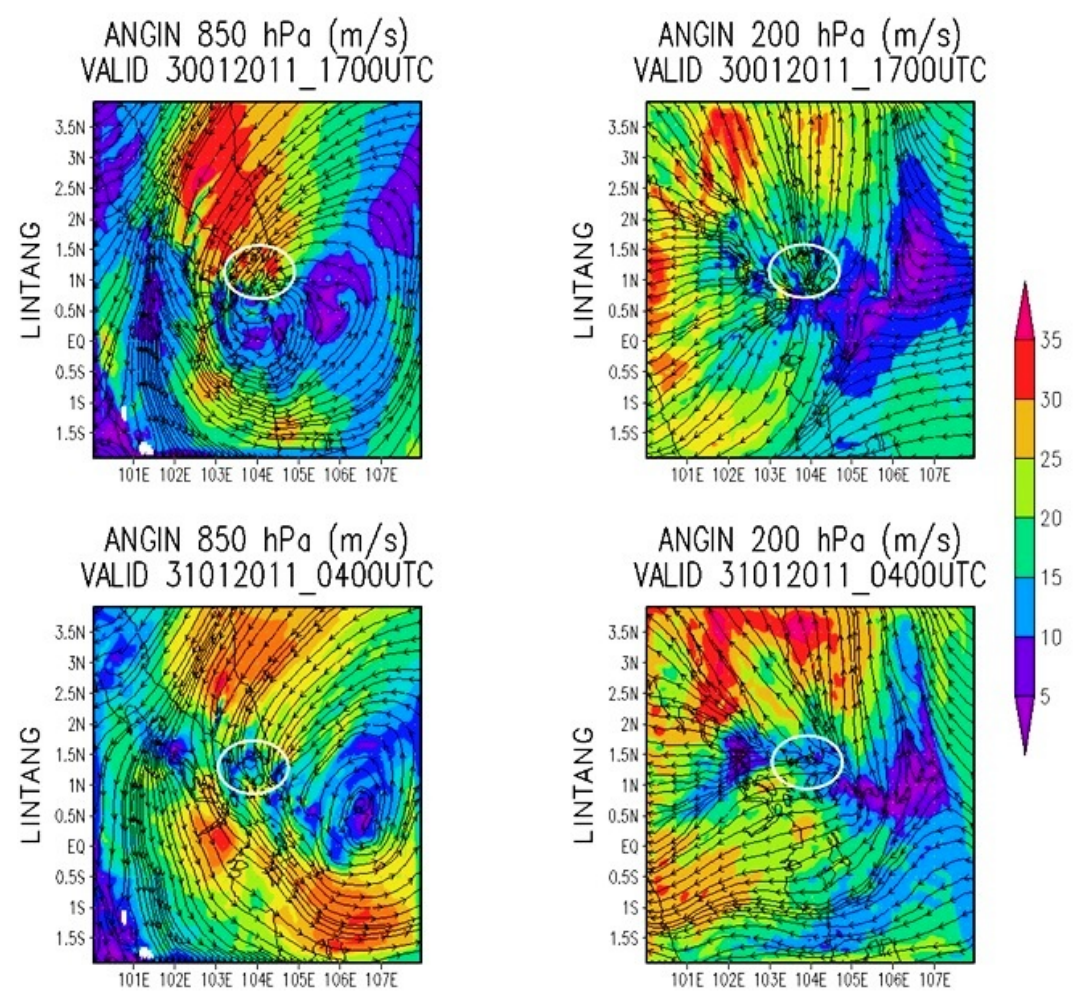

Gambar 4: Angin lapisan 850 dan $200 \mathrm{hPa}$.

VERTICAL VELOCITY $\left(\mathrm{ms}^{\wedge}-1\right)$ )VORTISITAS $\left(\mathrm{s}^{\wedge}-1\right) 850 \mathrm{hPo}(\mathrm{m} / \mathrm{s})$ 'RTICAL VELOCITY; SHEAR 850-200MB $(\mathrm{m} / \mathrm{s})$ BATAM 30-31 JANUARI 2011
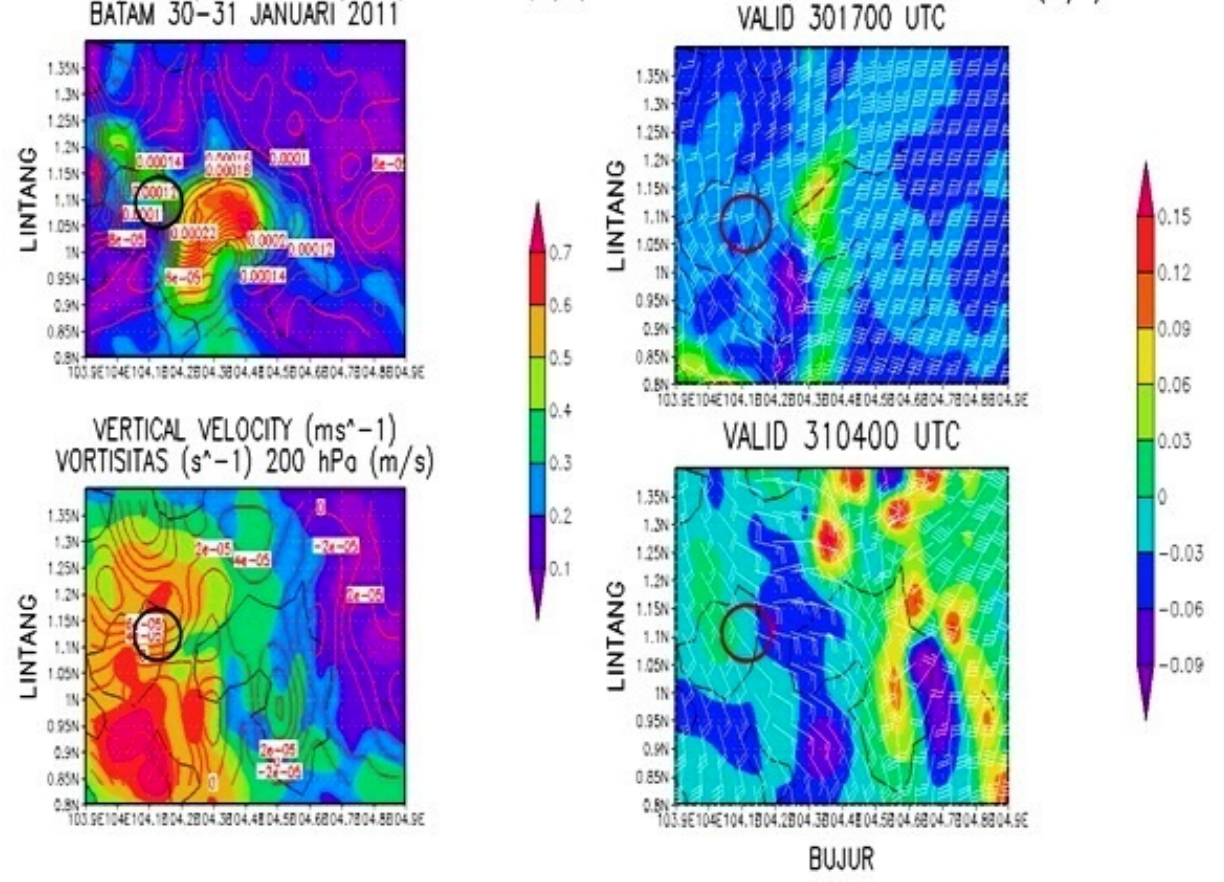

Gambar 5: Vortisitas dan vertical velocity lapisan 850 . 

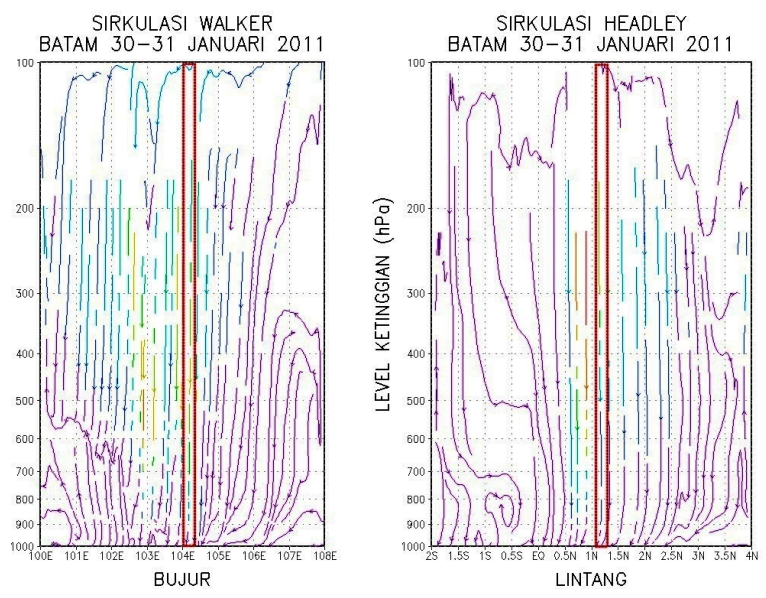

Gambar 6: Sirkulasi Hadley.

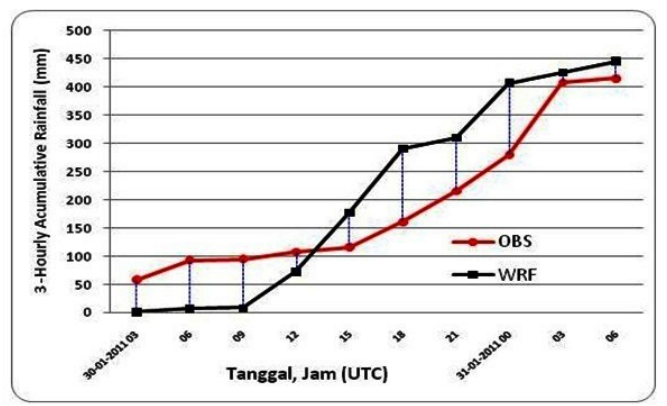

Gambar 7: Perbandingan akumulasi curah hujan WRF.

baban udara, sehingga dapat dipastikan akan adanya suatu fenomena cuaca signifikan (ekstrim) yang sedang terjadi.

Gambar 4 merupakan kecepatan dan arah angin sesaat sebelum hujan intensitas tinggi mengguyur Batam. Pada gambar tersebut daerah berlingkar putih merupakan titik observasi (Stasiun Meteorologi Hang Nadim Batam), dimana pada 30 Januari 2011 pukul 17.00 UTC (00.00 LT) kecepatan angin di lapisan $850 \mathrm{hPa}$ sekitar $25-35 \mathrm{~m} / \mathrm{s}$ dengan arah angin memusat, artinya terjadi konvergen pada daerah tersebut, namun bila dilihat dari kecepatan anginnya, ini termasuk angin kencang. Seharusnya bila mengikuti teori yang ada, ketika terjadi konvergensi atau pemampatan massa udara, kecepatan angin cenderung melemah. Sedangkan pada gambar yang ditunjukkan pada lapisan $200 \mathrm{hPa}$, angin cenderung divergen dengan kecepatan antara $15-25 \mathrm{~m} / \mathrm{s}$. Sehingga ketika pada jam tersebut di kedua lapisan diindikasikan awan Cumulonimbus telah mengalami tahap mature (dewasa), dimana updraft dan downdraft sama-sama kuat.

Adanya pemampatan udara di lapisan bawah disertai dengan pemburaian udara di lapisan atas mengindikasikan bahwa kolom udara antara kedua lapisan sedang terjadi aliran yang sangat kuat (udara dipompa masuk dari bawah dan dipompa keluar pada lapisan atas). Sedang pada gambar di baris bawah (31 Januari 2011), menunjukkan keadaan hujan tengah mereda, dimana pada lapisan $850 \mathrm{hPa}$ pemampatan massa udara tekah bergeser ke sebelah timur Batam, dengan ke-

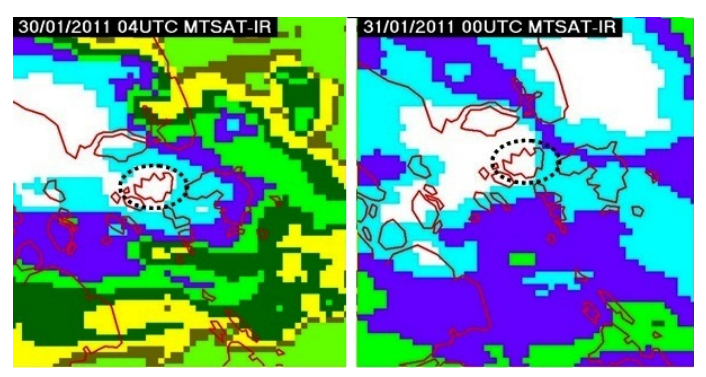

Gambar 8: Citra satelit Batam memiliki warna putih dengan ketentuan suhu puncak awan di bawah $-80^{\circ} \mathrm{C}$.

cepatan pada lapisan $850 \mathrm{hpa}$ maupun $200 \mathrm{hPa}$ antara 10-15 $\mathrm{m} / \mathrm{s}$. Artinya antara kedua lapisan angin cenderung telah stabil, ini dapat diindikasikan kolom udara pada kedua lapisan cenderung stabil, bisa jadi awan Cumulonimbus telah meluruh.

Gerak vertikal ke atas (Gambar 5) sesaat sebelum hujan intensitas tinggi mengguyur Batam dan sessat setelah hujan mulai mereda menunjukkan bahwa pada 30 Januari 2011 pukul 17.00 UTC (00.00 UTC), angin vertikal bernilai negatif (-), artinya angin bergerak turun [6], hal ini diindikasikan adanya downdraft dari awan Cumulonimbus. Dan bila dikaitkan dengan analisis sebelumnya, maka memang benar adanya bahwa pemusatan massa udara disertai dengan downdraft, artinya Cumulonimbus memang berada pada tahapan dewasa. Sedang untuk shear vertikal antara lapisan 850-200 hPa (ditunjukkan vektor), diketahui bahwa kecepatannya sekitar $20 \mathrm{~m} / \mathrm{s}$, artinya anatar kedua lapisan terajadi perbedaan kecepatan yang cukup tinggi, sehingga diindikasikan ada perputaran pada kolom udara anatar kedua lapisan. Sedang pada 31 Januari 2011 pukul 04.00 UTC (11.00 LT), angin vertikal bernilai antara - $0,03 \mathrm{~m} / \mathrm{s}$ sampai $0 \mathrm{~m} / \mathrm{s}$. Artinya udara masih bergerak turun, sebab pada jam tersebut keaadaan masih hujan, namun sudah mereda. Sedang untuk shera vertikal sendiri, dia cenderung lemah, artinya udara antara kedua lapisan sudah mulai stabil.

Nilai vortisitas selama 30 Januari 2011 pukul 00.00 UTC s/d 31 Januari 2011 pukul 06.00 UTC menunjukkan sepanjang waktu tersebut Batam tengah diguyur hujan dari intensitas tinggi hingga rendah. Lingkaran hitam merupakan titik observasi, diketahui bahwa pada lapisan $850 \mathrm{hPa}$ nilai vortisitas sekitar $0.00012 \mathrm{~s}^{-1}$, nilai positif (+) pada BBU mengindikasikan adanya pergerakan udara keatas oleh adanya perputaran kolom udara [7]. Ini terbukti dengan munculnya awan Cumulonimbus yang kemudian menyebabkan hujan bahkan banjir di Batam, sedang untuk rataan kecepatan angin vertikalpun adalah bernilai positif (+) bahkan disekitar titik observasi mencapai $0,7 \mathrm{~m} / \mathrm{s}$, artinya pada rentang hari tersebut rata-rata udara bergerak ke atas dengan kecepatan cukup tinggi, sehingga sangat memungkin bila Cumulonimbus yang terbentukpun kuat dan bertahan cukup lama. Untuk lapisan $200 \mathrm{hPa}$ nilai vortisitas sekitar $6 \times 10^{-5} \mathrm{~s}^{-1}$ artinya masih diindikasikan adanya kenaikan udara oleh adanya perputaran kolom udara dengan rataan angin vertikal yang juga masih mengindikasikan adanya gerakan udara keatas.

Gambar 6 merupakan sirkulasi walker dan headley pada 


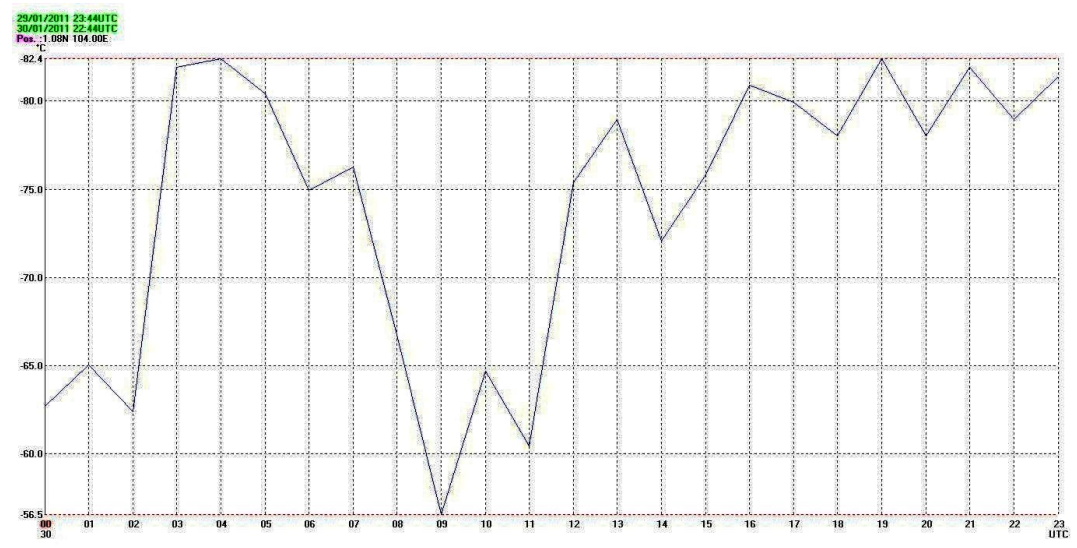

Gambar 9: Trend suhu puncak awan tanggal 30 Januari 2011.

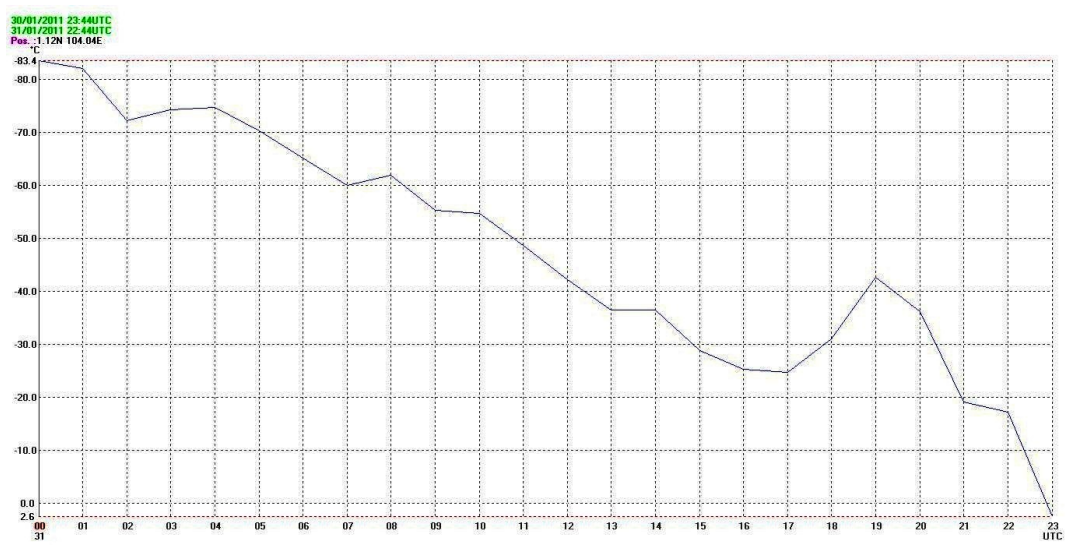

Gambar 10: Trend suhu puncak awan tanggal 31 Januari 2011.

titik observasi di Batam (kotak merah putus-putus), dimana pada penampang vertikal antara kedua sirkulasi tersebut secara rataan terjadai penurunan udara. Artinya baik udara yang bergerak secara utara-selatan (headley) maupun barat-timur (walker), keduanya menunjukkan adanya penurunan udara terhadap lapisan tekanan. Ini mengindikasikan pada rentang hari tersebut Cumulonimbus lebih banyak mengalami proses downdraft, ini terbukti dengan turunnya hujan pada rentang hari tersebut.

\section{Analisis Hujan}

Dalam kasus kejadian hujan lebat di Batam yang menyebabkan banjir, parameter-parameter cuaca saling memberikan andil dalam terjadinya proses konveksi yang kuat dan terbentuknya awan konvektif yang besar dan mempunyai masa hidup yang cukup lama. Semua kondisi tersebut menghasilkan suatu akibat yaitu hujan dengan intensitas yang sangat lebat. Intensitas hujan yang sangat lebat pada pencatatan di lapangan dilakukan perbandingan dengan hasil analisis menggunakan model WRF. Dengan melakukan akumulasi curah hujan tiap tiga jam secara terus menerus, didapatkan hasil pada Gambar 7.
Terdapat perbedaan pergerakan akumulasi curah hujan antara curah hujan pengamatan dan analisis model. Pada tanggal 30 Januari 2011 jam 03 UTC, hujan sudah tercatat pada pengamatan di atas $50 \mathrm{~mm}$ sedangkan analisis model menunjukkan belum adanya curah hujan yang signifikan. Analisis model menunjukkan peningkatan signifikan antara jam 09 hingga 18 UTC. Pada jam 06 UTC tanggal 31 Desesmber 2011 curah hujan akumulasi observasi sebesar 415,4 mm sedangkan analisis model menunjukkan $440 \mathrm{~mm}$.

\section{Analisis Citra Satelit (Sebagai Data Pendukung)}

Kondisi hujan lebat tanggal 30 sampai 31 Januari 2011 di Batam (Gambar 8) juga terdeteksi melalui citra satelit MTSAT. Dengan menggunakan citra infra merah melalui aplikasi sataid ditampilkan dengan mode Enhanced Infra Red Color. Menurut Dvorak [8] warna putih merupakan Coldest Dark Grey (CDG) dengan indikasi suhu puncak awan lebih rendah dari $-80^{\circ} \mathrm{C}$. Suhu yang sangat rendah tersebut mengindikasikan pula bahwa awan Cumulonimbus yang terdapat di atmoser Batam pada saat itu mempunyai puncak yang sangat tinggi dengan potensi curah hujan yang sangat ekstrim. Sedangkan pergerakan suhu puncak awan tiap jam pada tanggal 30 dan 31 Januari 2011 yang merupakan puncak hujan 
lebat dapat dilihat pada grafik dalam Gambar 9.

Pergerakan suhu puncak awan pada tanggal 30 Januari 2011

(Gambar 9) dengan melihat citra infra merah dapat menjelaskan kondisi awan yang didominasi oleh awan konvektif (Cumulonimbus) dengan suhu puncak awan sepanjang hari di bawah $-55^{\circ}$ C. Sedangkan pada hari berikutnya (Gambar 10), suhu puncak awan sangat rendah pada pagi hari dan mulai naik secara teratur seiring meredanya hujan lebat yang terjadi.

\section{SIMPULAN}

Berdasarkan hasil yang dijelaskan sebelumnya, ada beberapa kesimpulan. Hasil pengolahan model WRF pada tanggal 30 Januari 2011 mulai jam 00 UTC hingga tanggal 31 Januri 2011 jam 06 UTC memberikan penjelasan detil secara series waktu tentang beberapa parameter. Parameter suhu udara dan kelembaban udara menjelaskan kondisi sig- nifikan yang terjadi di atmosfer Batam saat terjadi hujan lebat. Kondisi kelembaban tinggi di atmosfer hingga lapisan 500 milibar membuat pertumbuhan awan terus berlanjut dan hujan terus terjadi dengan intensitas tinggi. Dari hasil analisis aliran udara (angin) menunjukkan adanya konvergensi (pemampatan massa udara). Vortisitas yang bernilai negatif mengindikasikan adanya pergerakan siklonik ke atas yang membantu proses konveksi dan pembentukan awan yang kuat. Sedangkan dari curah hujan akumulasi menunjukkan pola yang hampir sama dengan curah hujan akumulasi hasil observasi, namun terjadi keterlambatan kenaikan curah hujan hasil analisis model. Pembandingan hasil analisis dengan citra satelit MTSAT, memperjelas kondisi yang terjadi pada saat hujan lebat. Klasifikasi warna (Coldest Dark Grey) sangat jarang terjadi kecuali pada saat kondisi perawanan yang menjulang tinggi ke atas dengan suhu puncak awan paling rendah (di bawah $-80^{\circ} \mathrm{C}$ ) menunjukkan adanya hujan yang sangat lebat yang terjadi.
[1] SPB, Majalah Lentera, 02 (edisi September, 2011).

[2] Koran Haluan Kepri, Edisi 3459, 31 Januari 2011

[3] BMKG, Peraturan Kepala Badan Meteorologi Klimatologi dan Geofisika Nomor: KEP.009 Tahun 2010 tentang Prosedur Standar Operasional Pelaksanaan Peringatan Dini, Pelaporan, dan desiminasi Informasi Cuaca Ekstrim, BMKG,Jakarta, 2010.

[4] Gintang Sulung, dkk. 2011. Pengaruh Parameterisasi Kumulus terhadap Simulasi Angin Kencang di Makassar dengan Menggunakan WRF. Bandung: ITB.

[5] Tri wahyudi, dkk. 2011. Pelatihan Model WRF. Bandung: ITB.

[6] J.R. Holton, An Introduction to Dynamic Meteorology (Aca- demic Press: International Geophysics Series Volume 88, Fourth Edition, 2004).

[7] T.H. Seto, Mengapa Hanya Sedikit Awan Konvektif Yang Tumbuh Di Atas Daerah Bandung Pada Periode 10 Desember 1999 S.D 04 Januari 2000?, Jurnal Sains \& Teknologi Modifikasi Cuaca, 1 (1) (2000).

[8] V. Dvorak, Tropical cyclone intensity analysis using satellite data, NOAA Tech. Rep. NESDIS11, 47, 1984. [Available from NOAA/NESDIS, 5200 Auth Rd., Washington, DC 20233]. 